\title{
UJI DIAGNOSTIK SEDIAAN POTONG BEKU TUMOR PAYUDARA DI LABORATORIUM PATOLOGI ANATOMI PADANG
}

\author{
Aswiyanti Asri ${ }^{1}$, Susanto Winarko²
}

\begin{abstract}
Abstrak
Kanker payudara menempati urutan pertama tumor ganas pada wanita di Sumatera Barat dan merupakan penyebab kematian sebanyak $1.41 \%$ dari total kematian. Pemeriksaan potong beku menjadi salah satu pilihan dalam menegakkan diagnosis tumor payudara karena cepat dan akurasi yang cukup tinggi. Penelitian ini bertujuan untuk mengetahui akurasi sediaan potong beku pada tumor payudara yang didiagnosis di Laboratorium Patologi Anatomi di Padang, dengan konfirmasi histopatologi (blok parafin). Sebanyak 72 kasus tumor payudara yang dilakukan pemeriksaan potong beku, dikumpulkan dari laboratorium Patologi Anatomi RSUP Dr. M. Djamil dan RS Siti Rahmah Padang dari 1 Januari 2010 sampai dengan 31 Desember 2012. Data berupa hasil pemeriksaan potong beku dan histopatologi (blok parafin) dicatat, diolah dan dilakukan uji diagnostik dengan tabel kontingensi 2x2, kemudian dilakukan penghitungan sensitivitas, spesifisitas, nilai prediksi positif, nilai prediksi negatif, dan akurasi. Hasil uji diagnostik potong beku terhadap histopatologi pada kasus tumor payudara didapatkan sensitivitas $100 \%$, spesifisitas $95,65 \%$, nilai prediksi positif $98 \%$, nilai prediksi negatif $100 \%$, akurasi $98.6 \%$. Pemeriksaan potong beku sangat sensitif dan spesifik yang sangat bermanfaat untuk diagnosis tumor payudara yang cepat dan akurat.
\end{abstract}

Kata kunci: tumor payudara, potong beku, pemeriksaan histopatologi (blok parafin), uji diagnostik

\begin{abstract}
Breast cancer is the most common cancer among female in West Sumatera and cause of $1.41 \%$ of the death. Frozen section examination of breast has been used as a diagnostic procedure because this method need less time and have high level of accuracy. The aim of this study is to evaluate the accuracy of frozen section examination with histopathologic confirmation.

The study has been done retrospectively in 72 samples of breast tumor at the Anatomic Pathology of Dr.M.Djamil Public Hospital and Siti Rahmah Hospital Padang from January 1, 2008 to December 3, 2012. The result of frozen section and histopathology examination was collected and analyzed for counted the sensitivity and specificity value, positive predictive value, negative predictive value and accuracy value using contingency table $2 \times 2$. The result showed a $100 \%$ sensitivity, 95.65\% specificity, 98\% positive predictive value, 100\% negative predictive value and $98.6 \%$ accuracy. Frozen section examination is a highly sensitive and specific test that can be useful for diagnostic choice of breast tumor and it is time less and accurate.

Keywords: breast tumors, frozen section, histopathology examination (paraffin block), diagnostic test.

Afiliasi Penulis : 1. Bagian Patologi Anatomi, Fakultas Kedokteran Universitas Andalas, 2. Lab. Patologi Anatomi RS Telogorejo Semarang. Korespondensi: Aswiyanti Asri, Bagian Patologi Anatomi, Fakultas Kedokteran Universitas Andalas, Jl. Perintis Kemerdekaan No. 94 PO BOX 49 Padang 25127. Email: aswiyanti.asri@gmail.com, Telp/HP: $+6281264801469$
\end{abstract}




\section{PENDAHULUAN}

Berdasarkan data histopatologik dari Badan Registrasi Kanker Perhimpunan Dokter Spesialis Patologi Indonesia pada tahun 2006, karsinoma payudara di Indonesia menempati urutan kedua sebanyak 2148 orang (14.28\%) setelah karsinoma leher rahim. Di Padang, jumlah penderita kanker payudara berada diurutan pertama dengan jumlah penderita sebanyak 232 orang. ${ }^{1}$ Data terakhir dari WHO tahun 2011 menyebutkan kematian akibat kanker payudara di indonesia mencapai 20.052 atau $1,4 \%$ dari total kematian. ${ }^{2}$

Penegakkan diagnosis tumor payudara seringkali menyulitkan para klinisi terutama dokter bedah dalam memutuskan tindakan yang tepat saat operasi. Untuk itu dibutuhkan suatu pemeriksaan histopatologi yang cepat dalam membantu dokter bedah mengambil keputusan intra operatif. Salah satu pemeriksaan histopatologi yang sering dilakukan adalah frozen section atau potong beku yaitu teknik pemeriksaan histopatologi cepat dengan menggunakan pembekuan jaringan yang bertujuan untuk membantu diagnosis tentang ada atau tidaknya keganasan. Dalam bedah onkologi dan terutama pada patologi payudara, potong beku memungkinkan ahli bedah untuk mengambil keputusan terapi langsung, sehingga dapat menghemat biaya operasi dari pasien, yang kedua dapat mengurangi biaya rawat inap. Potong beku pada biopsi payudara yang teraba dapat dilakukan dengan tingkat akurasi yang tinggi (bervariasi antara 94\% dan $98 \%) .^{3}$

Teknik potong beku ini sebenarnya merupakan prosedur yang sulit dilakukan oleh seorang ahli patologi didalam prakteknya karena membutuhkan pengalaman, pengetahuan, keterampilan teknis, dan keahlian diagnostik dalam membuat keputusan yang akurat, selain itu diagnosis yang dibuat oleh seorang patolog dalam teknik potong beku memiliki konsekuensi terapi bagi pasien.

Ketidakcocokan perbandingan antara hasil potong beku dengan hasil akhir blok parafin bisa disebabkan oleh adanya diagnosis negatif palsu, sedang diagnosis palsu yang dapat memberikan konsekuensi bagi pasien adalah bila terjadi hasil diagnosis positif palsu. Dengan demikian analisa keakuratan pada metode diagnosis potong beku sangat penting untuk meminimalkan pembedahan yang tidak diperlukan. ${ }^{4}$

Berdasarkan latar belakang tingginya kasus karsinoma payudara khususnya karsinoma payudara duktal invasif di Indonesia terutama di Sumatera Barat yang memerlukan diagnosis yang cepat dan akurat, maka peneliti tertarik untuk mengetahui uji diagnostik sediaan potong beku pada tumor payudara yang didiagnosis di laboratorium Patologi Anatomi di Padang.

\section{METODE}

Sebanyak 72 kasus tumor payudara dilakukan pemeriksaan potong beku dari tanggal 1 Januari 2010 sampai dengan 31 Desember 2012, di Laboratorium Patologi Anatomi RS M. Djamil dan RSI Siti Rahmah Padang. Jumlah kasus dihitung berdasarkan rumus simple random sampling. Desain penelitian ini adalah uji diagnostik, dengan baku emas hasil pemeriksaan histopatologi massa tumor yang sama (blok parafin). Data yang terkumpul 
diolah dan dilakukan uji diagnostik dengan tabel kontingensi $2 \times 2$, kemudian dilakukan penghitungan sensitivitas, spesifisitas, nilai prediksi positif, nilai prediksi negatif, dan akurasi.

\section{HASIL DAN PEMBAHASAN}

Dari 72 kasus tumor payudara yang dilakukan pemeriksaan potong beku dan histopatologi (blok parafin), didapatkan karakteristik sebagai berikut:

Tabel 1. Distribusi jenis tumor payudara dari pemeriksaan potong beku

\begin{tabular}{ccc}
\hline Jenis tumor & Jumlah & $\%$ \\
\hline Tumor jinak & 22 & 30.5 \\
Tumor ganas & 50 & 69.5 \\
\hline Total & 72 & 100 \\
\hline
\end{tabular}

Tabel 2. Jenis tumor jinak payudara dari hasil konfirmasi blok parafin (histopatologi)

\begin{tabular}{lcc}
\hline \multicolumn{1}{c}{ Jenis tumor } & Jumlah & $\%$ \\
\hline $\begin{array}{l}\text { Fibroadenoma } \\
\text { mammae }\end{array}$ & 5 & 23 \\
$\begin{array}{l}\text { Fibrocystic disease } \\
\text { Benign phylloides } \\
\text { tumor }\end{array}$ & 8 & 36 \\
$\begin{array}{l}\text { Adenoma } \\
\text { mammae }\end{array}$ & 1 & 5 \\
Abses mammae & 1 & 5 \\
Mastitis & & \\
$\begin{array}{l}\text { Epithelial } \\
\text { hyperplasia }\end{array}$ & 1 & 5 \\
\hline \multicolumn{1}{c}{ Total } & 4 & 18 \\
\hline
\end{tabular}

Tabel 3. Jenis tumor ganas payudara dari hasil konfirmasi blok parafin (Histopatologi)

\begin{tabular}{lcc}
\hline \multicolumn{1}{c}{ Jenis tumor } & Jumlah & $\%$ \\
\hline $\begin{array}{l}\text { Invasive Ductal } \\
\text { Carcinoma }\end{array}$ & 38 & 76 \\
$\begin{array}{l}\text { Invasive Lobular } \\
\text { Carcinoma }\end{array}$ & 9 & 18 \\
$\begin{array}{l}\text { Malignant Phylloides } \\
\text { Tumor }\end{array}$ & 1 & 2 \\
MucinousCarcinoma & 2 & 4 \\
\hline \multicolumn{1}{c}{ Total } & 50 & 100 \\
\hline
\end{tabular}

Tabel 4. Uji Diagnostik pemeriksaan Potong Beku terhadap Histopatologi

\begin{tabular}{llccl}
\hline & \multicolumn{4}{c}{ Histopatologi } \\
\cline { 2 - 5 } & & Ganas & Jinak & Total \\
\hline Potong & Ganas & 49 & 1 & 50 \\
Beku & Jinak & 0 & 22 & 22 \\
\hline & Total & 49 & 23 & 72 \\
\cline { 2 - 5 }
\end{tabular}

Sensitivitas: $49 / 49 \times 100 \%=100 \%$

Spesifisitas: $22 / 23 \times 100 \%=95,65 \%$

Nilai Prediksi Positif: 49/50 x 100\%=98\%

Nilai Prediksi Negatif: $22 / 22 \times 100 \%=100 \%$

Akurasi : $71 / 72 \times 100 \%=98,6 \%$

Potong beku adalah suatu prosedur yang telah mapan untuk memberikan diagnosis yang cepat dari sampel intraoperatif sehingga memungkinkan dokter ahli bedah untuk segera membuat keputusan dan langkah selanjutnya, oleh sebab itu potong beku dituntut akurasi yang tinggi agar dokter ahli bedah memiliki keyakinan dalam memberikan keputusan terapi selanjutnya.

Didalam pelaksanaannya teknik potong beku ini sebenarnya merupakan prosedur yang sulit dilakukan oleh seorang ahli patologi didalam prakteknya karena membutuhkan pengalaman, pengetahuan, ketrampilan teknis dan keahlian diagnostik dalam membuat keputusan yang akurat, selain itu diagnosis yang dibuat oleh seorang patolog dalam tehnik potong beku memiliki konsekuensi terapi bagi pasien.

Sensitivitas merupakan proporsi dari subyek yang berpenyakit yang mempunyai uji yang positif, dan menunjukan seberapa baik sesuatu uji tersebut didalam mengidentifikasi pasien dengan penyakit. Pada uji sensitivitas Fessia et al melaporkan sensitivitas potong beku adalah $94.6 \%$ sedangkan pada penelitian ini adalah $100 \%$ 
sehingga bisa dikatakan hasil penelitian ini sangat sensitif atau sangat baik dalam mengidentifikasi pasien dengan penyakit. $^{5}$

Spesifisitas merupakan proporsi dari subyek tanpa penyakit yang menunjukkan uji negatif, yang menunjukkan seberapa baik sesuatu uji dalam mengidentifikasi orang tanpa penyakit. Fessia melaporkan hasil sepesifisitasnya $100 \%$ sedangkan pada hasil penelitian ini adalah 95.65\%, hal ini dikarenakan terdapat satu kasus positif palsu yang dilaporkan yaitu mastitis yang pada saat potong beku diduga suatu keganasan. Seperti diketahui bahwa pada suatu proses peradangan yang hebat (mastitis) akan mengakibatkan perubahan reaktif didalam bentuk sel disamping penyulit lain yang sering didapatkan potong beku seperti sel yang sembab, inti lebih besar dan cenderung hiperkromatik serta sitoplasma yg bervakuol. Beberapa penyulit yang ditemukan dalam menegakkan diagnosis sediaan potong beku antara lain terdapatnya kristal es dalam stroma yang edema sehingga memberikan gambaran artefak, gambaran inti yang cenderung menjadi lebih besar, gambaran kromatin tampak lebih kromatik dibandingkan blok parafin, gambaran sitoplasma lebih bervakuolisasi, dan permasalahan teknis seperti ketajaman pisau, over atau under freezing, pewarnaan, gelembung udara, serta ketebalan sediaan. ${ }^{6}$

Didalam uji diagnostik diperlukan beberapa uji nilai prediksi yaitu nilai prediksi positif dan nilai prediksi negatif yang membantu kita menentukan apakah pasien benar-benar menderita sakit atau tidak berdasarkan hasil uji. Nilai prediksi positif yang merupakan probabilitas dari seseorang dengan hasil uji positif benar-benar mempunyai penyakit dan uji ini dipengaruhi oleh hasil uji spesifisitasnya. Fessia melaporkan nilai prediksi positif dengan 100\%, sedangkan pada kasus ini didapatkan hasil 98\% karena hal ini dipengaruhi dari hasil spesifisitasnya.

Uji nilai prediksi negatif digunakan untuk mengetahui probabilitas seseorang dengan hasil uji negatif adalah benar-benar tidak mempunyai penyakit dan uji ini dipengaruhi oleh hasil uji sensitivitasnya. Pada uji ini Fessia melaporkan hasilnya $97.8 \%$ sedang pada kasus ini dilaporkan hasilnya $100 \%$.

Akurasi dari diagnosis potong beku secara umum pada semua kasus dilaporkan bervariasi. Kaufman dalam penelitiannya melaporkan akurasi potong beku secara umum adalah $97.1 \%$, sedangkan Fariba Abbasi dalam artikelnya melaporkan akurasi potong beku diantara 91.5\%-97.4\%. ${ }^{7,8}$ Fessia dalam penelitiannya melaporkan akurasi potong beku khusus pada kanker payudara adalah $98.3 \%$ sedang pada penelitian ini didapatkan akurasinya adalah $98.6 \%$ sehingga bisa disimpulkan pada kasus penelitian ini memiliki akurasi yang diatas rata-rata.

Walaupun dari penelitian ini didapatkan akurasi yang cukup bagus, ada beberapa keterbatasan dalam potong beku yang harus diperhatikan oleh seorang ahli patologi yaitu (a) keterbatasan atau kesalahan sampling seperti sampel jaringan yang jelek, kesalahan pemilihan jaringan di laboratorium, degenerasi atau nekrosis tumor yang luas, kesalahan dalam penilaian invasi ke kapsul atau vaskular, (b) keterbatasan masalah teknis yaitu artefak dari pembekuan, kualitas yang 
buruk, misalnya; terlalu tebal atau terlipat, morfologi sel yang membengkak karena pengaruh cairan, pewarnaan yang tidak baik, (c) kesalahan pada interpretasi yaitu tumor yang sulit untuk didiagnosis seperti angiosarkoma atau signet ring cells, tumor yang heterogen terutama sarkoma, tumor campur dan tumor bifasik, derajat diferensiasi tumor seperti pada glioma di otak dan kondrosarkoma pada tulang, penentuan yang sulit dari pankreatitis kronis dengan karsinoma pankreas. $^{9} \quad$ Adanya keterbatasan ini menyebabkan tidak semua jenis tumor direkomendasikan untuk didiagnosis menggunakan potong beku.

\section{SIMPULAN}

Hasil uji diagnostik potong beku terhadap histopatologi pada kasus tumor payudara didapatkan sensitivitas $100 \%$, spesifisitas $95.65 \%$, nilai prediksi positif $98 \%$, nilai prediksi negatif $100 \%$, serta akurasi 98.6\%. Pemeriksaan potong beku dapat menjadi pilihan diagnostik pada tumor payudara karena memerlukan waktu yang singkat dan akurasi yang tinggi. Perlu dipertimbangkan pemerik-saan imprint atau scrapping dalam setiap pemeriksaan potong beku untuk membantu menegakkan diagnosis potong beku sekaligus sebagai pem-banding dan membantu meningkatkan akurasi.

Perlu penelitian lanjutan dengan membandingkan triple test diagnostik yaitu pemeriksaan klinis, radiologis dan sitologi aspirasi jarum halus terhadap potong beku.

\section{DAFTAR RUJUKAN}

1. Badan Registrasi Kanker IAPI. Data Histopatologik. Badan Registrasi Kanker. Perhimpunan Dokter Spesialis Patologi Indonesia. Yayasan Kanker Indonesia.

2. Ahmedin Jemal, Freddie Bray, Melissa M, et al. Global Cancer Statistics. Ca Cancer J Clin. 2011. 61:69-90

3. Nuzhat S, Naila K. Validity of frozen section in the diagnosis of breast lumps: 5 years experience at the Aga Khan University Hospital, Departemen of Pathology: The Aga Khan University Hospital. Karachi, 2005

4. Rafael DP da Silva. Diagnostic accuracy of frozen section test for surgical disease. University Hospital Benefit Association, University of Marlia Sao Paolo. 2011.38(3):149-54

5. Fessia L, Ghiringhello B, Arisio R, Botta G, Aimone V. Accuracy of frozen section diagnosis in breast cancer detection: A review of 4436 biopsies and comparison with cytodiagnosis. 1984.179:61-6

6. Jessica W. Frozen section troubleshooting artifacts and poor technique, Pathology Outlines.com, 2011, diunduh dari: http://www.pathologyoutlines.com/topic/froz ensectiontroubleshooting.html

7. Kaufman Z, Lew S, Griffel B, Dinbar A. Frozen section diagnosis in surgical pathology, a prospective analysis of 526 frozen section. 1986. 15:57(2):377-9

8. Fariba A, Zahra Y, Adel A. Accuracy of frozen section. Iranian Jour Of Pathol. 2012.7(1):3-8

9. Hasnan J. Intra operative frozen section consultation: concepts, applications and limitations. University Sains Malaysia. 2006. 